Portland State University

PDXScholar

1977

\title{
Self-esteem and the Elderly : an Exploratory Study of a Residential Population in a Home for the Aged
}

Vernon E. Hoffer

Portland State University

Follow this and additional works at: https://pdxscholar.library.pdx.edu/open_access_etds

Part of the Gerontology Commons, and the Social Work Commons Let us know how access to this document benefits you.

\section{Recommended Citation}

Hoffer, Vernon E., "Self-esteem and the Elderly : an Exploratory Study of a Residential Population in a Home for the Aged" (1977). Dissertations and Theses. Paper 2565.

https://doi.org/10.15760/etd.2563

This Thesis is brought to you for free and open access. It has been accepted for inclusion in Dissertations and Theses by an authorized administrator of PDXScholar. Please contact us if we can make this document more accessible: pdxscholar@pdx.edu. 
AN ABSTRACT OF THE THESIS OF Vernon E. Hoffer for the Master of Social Work presented July 21, 1977.

Title: Self-Esteem and the Elderly: An Exploratory Study of a Residential Population in a Home for the Aged.

APPROVED BY MEMBERS OF THE THESIS COMMITTEE:
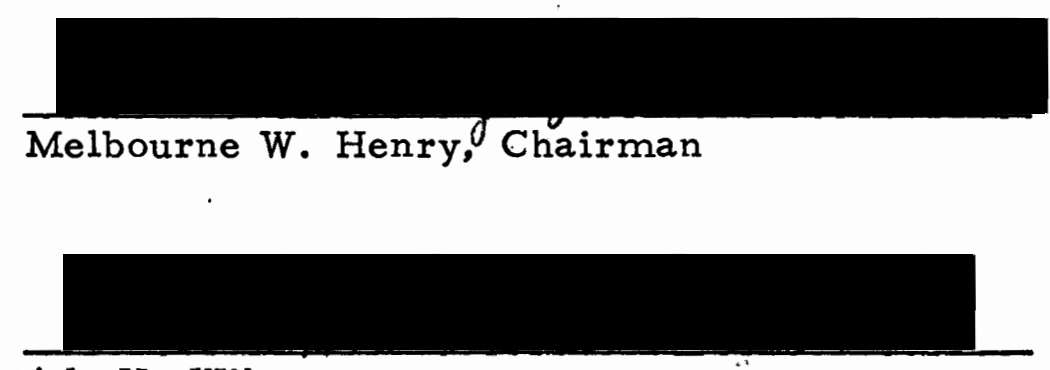

Ada K. Wilson

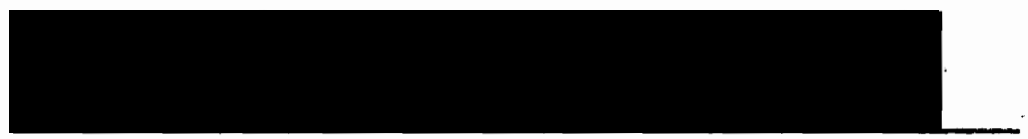

Leonard D. Cain

The two primary purposes of this exploratory study were (1) to establish the theoretical tenability of focusing on the mainten- ance of self-esteem as a means for enhancing the quality of life in the institutionalized elderly, and (2) to identify factors related to selfesteem in a home for the aged sample.

Literature reviewed relative to the importance of self-esteem, its development, and its maintenance or change indicated that (1) self- 
esteem is related to personal satisfaction and effective social functioning; (2) self-esteem develops and is maintained or changed as a function of factors in an individual's immediate interpersonal environment; and (3) institutionalization itself is not the critical factor affecting the self-esteem of institutionalized persons.

In order to examine both the nature of and factors related to self-esteem in a sample of home for the aged residents, a 45 -item interview schedule was administered to residents of the Pythian Home in Vancouver, Washington. A total of twenty-two residents, consisting of seventeen women and five men, participated in the study. The subjects had a mean age of 82.7 and a mean length of residence in the Pythian Home of 6.2 years.

The interview schedule included Rosenberg's self-esteem scale (RSE) and questions designed to identify variations in the subjects' demographic characteristics, activities, feelings, and opinions which could be codified and tested for relationship to self-esteem. RSE was scored by constructing a nine-point Guttman scale. The coefficient of reproducibility for the scale was 0.93 .

The following eleven variables were tested for significant relationship to self-esteem; health, age, sex, education, length of residence, reminiscence, communality with other residents, residence status (boarding or nursing), room occupancy (single or double), visits by a significant other, and participation in crafts. In order to 


\section{SELF-ESTEEM AND THE ELDERLY: AN EXPLORATORY STUDY OF A RESIDENTIAL POPULATION IN \\ A HOME FOR THE AGED \\ by \\ VERNON E. HOFFER}

A the sis submitted in partial fulfillment of the requirements for the degree of

MASTER OF SOCIAL WORK

Portland State University

1977 
TO THE OFFICE OF GRADUATE STUDIES AND RESEARCH:

The members of the Committee approve the thesis of Vernon E. Hoffer presented July 21, 1977.

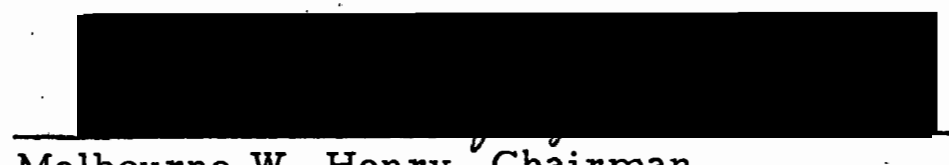

Melbourne W. Henry, Chairman

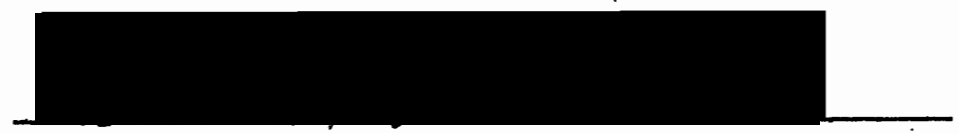

Ada K. Wilson

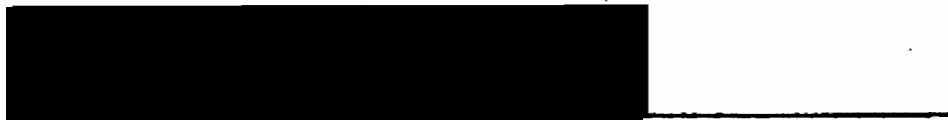

Leonard D. Cain

\section{APPROVED:}

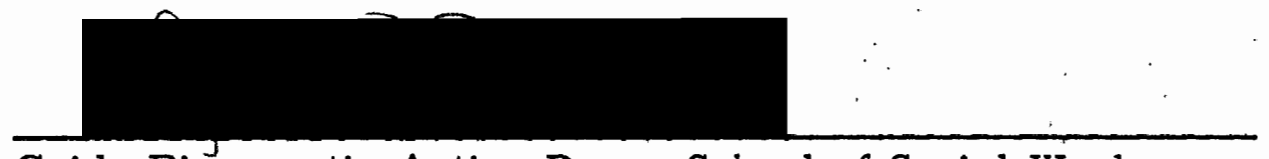

Guido Pinamonti, Acting Dean, School of Social Work

Stanley E. Rauch, Dean of Graduate Studies and Research 
TABLE OF CONTENTS

PAGE

LIST OF TABLES

CHAPTER

I INTRODUCTION .............. I

II REVIEW OF THE LITERATURE...... 6

Focus .................. 6

Definition of Terms

Theoretical Propositions

Relevant Theory and Research :.....

Effect of Immediate Interpersonal

Environment

Changes in Self-Conception

Effect of Institutionalization

Relationship to Personal Satisfaction

Self-Esteem and the Aged . . . . . . 19

Conclusion ...................... 21

III METHODOLOGY ............. 23

Selection and Characteristic s of Subjects . . 23

Selection

Characteristics

Instrument and Procedure ....... 25

Instrument

Procedure 
Limitations of the Study .........

IV RESULTS ................

Self-Esteem Analysis.........

Comparison Group Analysis ...... .

Statistical Analysis

Relationship to Previous Findings

Descriptions of Uncodified Responses ...

41

V SUMMARY AND CONCLUSIONS ......

REFERENCES ...................... 


\section{LIST OF TABLES}

TABLE

PAGE

I Frequency Distribution of Self-

Esteem Scores . . . . . . . .

II Positive Responses to Self-Esteem

Scale Items .......... 35

III Self-Esteem Means, Standard Deviations and $T$ Values of Comparison Groups . $\quad 37$

IV Mean Self-Esteem Scores of Age Groups. . 


\section{CHAPTER I}

\section{INTRODUCTION}

The aim of this exploratory study is twofold: first, to establish a theoretical base for focusing on the maintenance of selfesteem as a means of enhancing the quality of life in the institutionalized aged and, second, to identify factors related to self-esteem in a sample of residents in a home for the aged. The former will be achieved through a literature review and the latter by a survey of residents in a home for the aged. The literature review will concentrate on the nature of self-esteem and its relationship to factors in an individual's environment. The survey of home for the aged residents will address the following questions: Do these people have a problem maintaining self-esteem? and, What are the significant factors related to their self-esteem?

Branden (1976, p. 110) has defined self-esteem as "the conviction that one is competent to live and worthy of living." According to Coopersmith (1967, p. 2), there is a "widely held belief that self-esteem is significantly associated with personal satisfaction and effective functioning." The results of two major studies (Rosenberg, 1965; Coopersmith, 1967) on this topic indicate that 
self-esteem is intimately related to an individual's psychosocial needs.

Routh (1968, p. 48) has identified the psychological and emotional needs of the institutionalized elderly as "the desire... to feel loved, wanted and accepted; to feel safe and secure; to feel important, significant and worthwhile." In recent years it has become increasingly apparent that institutions for the elderly, as a whole, tend to neglect the psychosocial needs of their residents. Several writers (Routh, 1968; Entman, 1961; Schwartz, 1975) have noted that these facilities tend to focus almost exclusively on providing for the physical needs of their residents. According to Schwartz (1975, p. 471):

... an overemphasis on the delivery of medical services (that which makes life "possible") together with neglect of the psychosocial aspects of care (that which makes life "worthwhile") tend to directly revage and diminish self-esteem.

In view of the foregoing, it seems clear that understanding the nature of self-esteem and identifying factors related to selfesteem in the institutionalized aged should be of paramount interest to professionals charged with providing care for this population. The significance of this area of inquiry to the social work profession is readily apparent upon examination of the mission of social work and the plight of the elderly in our society. Siporin (1975, p. 3) observed that: 
Social work, in its essential character, values, purposes, and practice, responds to human needs ... Social work is defined as a social institutional method of helping people to prevent and resolve their social problems, to restore and enhance their social functioning.

In discussing the plight of the elderly in our society, Brody (1971, p. 55) noted:

$\therefore$ the aging phase of life in our society is often charcterized by the relative abruptness, clustering, and dynamic interaction of what have been termed the "insults" of aging. These assaults, which occur with increasing frequency as one moves through the aging phase of life toward advanced old age, include decrements in physical and mental capacities; chronic and/or catastrophic illness; interpersonal losses such as death or severe illness of spouse, or other relatives, peers, and even adult children; diminished income, cessation of productive working experience, and loss of social roles and status.

She concluded that the "nature" and "number" of the se problems make the elderly a "high risk" with regard to developing a need for assistance in meeting their psychological and social needs. The fact that institutionalized aged persons are faced.with the additional "insults" of separation from their home, family, and friends, as well as being placed in a position of extreme dependency, make them even more prone to needing assistance in meeting their psychosocial needs. The high probability that the institutionalized aged will require assistance in meeting their psychosocial needs, together with social work's commitment to respond to human needs, legitimate this population as a subject for both social work practice and re- 
search. The present study is a response to the latter.

The setting for this study was the Oregon-Washington Pythian Home, a home for the aged owned and operated by the Knights of Pythias, a fraternal order. This facility; located in Vancouver, Washington, was established in 1924 and accepts both nursing care and boarding residents. It is a three-story structure with boarding residents on the first and third floors and nursing residents on the second floor. One-third of the rooms is single occupancy and twothirds, double. In addition to the residents' rooms, the facility includes a large living room, a dining room, several comfortably furnished sitting rooms, a crafts room, and a combination beauty salon/barber shop.

At the time of the study there were 35 residents in the home, 29 in the nursing section and six in boarding rooms. Of the 35 residents, there were 28 women and seven men. General characteristics of Pythian Home residents include the following: They come from middle-class backgrounds; they are long-term members of either Knights of Pythias or the Temple of Pythian Sisters; and they are self-referred to the home.

The Pythian Home employs a staff of 27 full- and part-time employees. These include an administrator, an assistant administrator/activities director, an office clerk, three registered nurses, one part-time and two full-time licensed practical nurses, six 
nurses aides, three cooks, three waitresses, three laundry workers, two housekeepers, and a maintenance man. In addition, the home employs consultants from several disciplines to meet mandated requirements of local, county, state, and federal governments. The home enjoys a favorable reputation throughout the region with a high demand and minimal staff and patient turnover. 


\section{CHAPTER II \\ REVIEW OF THE LITERATURE}

FOCUS

The literature relating to self-esteem is too vast and divergent for a comprehensive review in a work of this nature. Therefore, the following literature review will focus solely on the theoretical formulations and empirical studies which led the author to conclude that self-esteem is affected by factors in an individual's immediate interpersonal environment. The literature review will be structured as follows: Definition of terms pertinent to self-esteem research; presentation of the theoretical formulations on which the study is based; examination of relevant theory and research pertaining to the theoretical premises; and research related to self-attitudes in the aged.

\section{Definition of Terms}

The terms which are pertinent to this study are self-concept, self-esteem, morale, and significant other. Although these terms have been subjected to numerous interpretations in the lite rature, the following definitions seem to capture the essence of their 
meanings.

"Self-concept .... (i.s) the organized cognitive structure derived from one's experience of his own self, " (McDavid and Harari, 1974, p. 184). An individual's self-concept consists of his perception of his characteristics, capacities, roles, and activities. "Self-esteem is the evaluative component of self-perception, the extent to which one likes himself," (McDavid and Harari, 1974, p. 184). In general terms, self-esteem refers to the positive or negative attitude an individual holds toward himself.

"... morale is a personal comparison of self-worth with a realization of loss of socially important roles," (Back, 1971, p. 296).

A significant other is "one whose opinions and actions 'matte $r$ ' to the individual, one whose esteem he values, and whose disapproval he seeks to avoid," (Webster and Sobieszek, 1974, p. 13). It should also be noted that the term self-concept denotes self-esteem when preceded by an evaluative adjective (e.g., positive or negative).

Theoretical Propositions

The theoretical propositions on which this study is based are as follows:

1. Self-esteem evolves and is maintained or changed through 
social interaction.

2. The immediate interpersonal environment provides the criteria through which an individual defines and evaluates himself.

3. Self-attitudes are modified due to changes in the individual's social environment even though, once established, they are resistant to change.

4. Institutionalization, per se, is not the critical factor affecting the self-esteem of institutional residents.

5. An individual's level of self-esteem is related to personal satisfaction and his ability to function effectively.

\section{RELEVANT THEORY AND RESEARCH}

There is as yet no generally accepted theory of self-esteem. Most investigators of this construct, however, cite the works of William James, Charles Horton Cooley, and George H. Mead as their theoretical base. Although these men did not focus exclusively on self-esteem, the topic did receive thoughtful consideration in their works. James focused primarily on the components of self-esteem, while Cooley and Mead focused on the development of self-esteem. Jame's' two most significant contributions to self theory are as follows: An individual's concept of self consists of several components, and self-esteem is a function of how well an individual lives 
up to what he expects of himself. The primary components of the self-concept, according to James (1952, pp. 188-191), are the material self, the social self, and the spiritual self. The material self consists of an individual's body and his material possessions; the social self is the recognition one gets from others; and the spiritual self is one's "subjective being, his psychic faculties or dispositions." James theorized that the components of the selfconcept are evaluated differentially by each individual. For example, a priest would likely be more heavily invested in his spiritual self than in his material self.

According to James (1952, p. 200), self-esteem is a function of how well an individual lives up to his aspirations in a valued area. He described this process in the following manner:

It (self-feeling) is determined by the ratio of our actualities to our supposed potentialities; a fraction of which our pretensions are the denominator and the numerator our successes; thus, Self-esteem $=\frac{\text { Success }}{\text { Pretensions }}$.

Later theorists have clarified James' formulation by defining selfesteem as the degree of congruence between an individual's ideal and actual self-concepts.

The works of Cooley and Mead are related to James' concept of the social self. According to their formulations there is no concept of the self except that which an individual integrates from interaction with others in his environment. Cooley (1964, p. 179) 
stated that, "The social self is simply any idea, or system of ideas, drawn from communicative life, that the mind cherishes as its own." The key element in Cooley's formulation is that an individual's concept of self is derived from imagining how he appears in the minds of others. His description of this process, which he labeled the "looking-glass self," was presented as follows (Cooley, 1964, p. 184):

As we see our face, figure, and dress in the glass, and we are interested in them because they are ours, and pleased or otherwise with them according as they do or do not answer to what we should like them to be; so in imagination we perceive in another's mind some thought of our appearance, manners, aims, deeds, character, friends, and so on, and are variously affected by it.

It was Cooley's contention, then, that self-esteem is a function of the individual's imagination of the judgment others have of him.

Mead, like Cooley, hypothesized that one's concept of self is derived from social interaction. According to Mead (1934, p. 140), "The self, as that which can be an object to itself, is essentially a social structure, and it arises in social experience." He described the development of one's self-concept as follows (Mead, 1934, p. 158):

... the re are two general stages in the full development of the self. At the first of these stages, the individual's self is constituted simply by an organization of the particular attitudes of other individuals toward himself and toward one another in the specific social acts in which he participates with them. But 
at the second stage in the full development of the individual's self that self is constituted not only by an organization of the se particular individual attitudes but also by an organization of the social attitude of the generalized other or the social group as a whole to which he belongs.

Mead's contribution to self theory is that the self-concept is a developmental process and that the development consists, first, in incorporating the reflected attitudes of significant others in an individual's environment; and second, from incorporating the attitudes of his social group as a whole.

Later contributions to self-esteem theory are largely extensions and clarifications of the works of James, Cooley, and Mead. The works of these early writers seem to indicate the following two sources of self-esteem: the reflected appraisals of others and how well an individual lives up to his personal standards and values. However, Luck and Heiss (1972) have suggested that the latter fits into the social interactionist theory since personal standards are learned from others.

Effect of Immediate Interpersonal Environment

The two most significant empirical works on self-esteem, studies by Rosenberg (1965) and Coopersmith (1967), were based on the theoretical constructs of James, Cooley, and Mead. Both the se investigators found evidence that an individual's immediate inter- 
personal environment has more effect on his self-esteem than society as a whole. Rosenberg (1965), in his research on selfesteem with an adolescent population, found that Jewish adolescents were more likely to have high self-esteem than adolescents from Catholic and Protestant religions even though the latter religions are more highly regarded by society. He concluded (Rosenberg, 1965, p. 80):

Groups are, indeed, differentially evaluated in the broader society, but, for the child, a more effective interpersonal environment is the neighborhood ... Since, in general, minority group members are probably as likely to band together as majority group members, the minority group child may receive as much social support and acceptance as the majority group child. This may be one reason why, for the child, the pres tige of his membership groups in the broader society may have relatively slight effect upon his level of self-acceptance.

Coopersmith (1967), in a study with preadolescents, found no significant relationship between either social class or religion and selfesteem. According to Coopersmith (1967, p. 86):

These results suggest that the psychological bases of esteem are more dependent on close, personal relationships and the immediate environment than upon material benefits or prestige rankings in the community at large ... it is the experiences within one's own social reference group that determines one's social definition of success - not the broader societal context.

The proposition that the immediate social environment influences the self-concepts of the elderly has been investigated by 
Kahana and Coe. They (Kahana and Coe, 1969, p. 264) proposed that, "The general environment of the institution which the resident enters and its new social system may be viewed as that social context affecting his self-concept." In examining this issue, they found that the views of the institutional residents became more congruent with those of the staff as a function of length of institutionalization. These results indicate that the residents incorporated the views of the staff into their own self-conceptions.

Changes in Self-Conception

The contention that the self-concept is relatively resistant to change has evolved from Leon Festinger's theory of cognitive dissonance. Festinger (1957, p. 158) explained this theory as follows:

If one puts together the notion that people will tend to avoid exposing themselves to new information which they expect would increase dissonance and the finding that, even if forcibly or inadvertently exposed to such potentially dissonance increasing information, they will frequently manage to evade its impact by misperception, disbelief, or some other equally serviceable process, we are then led to the conclusion that it is very difficult to change an opinion that already exists if it is consonant with existing behavior or with an existing cluster of attitudes and opinions.

Carl Rogers has applied this theory to changes in self-conception. According to Rogers (1951, p. 503):

As experiences occur in the life of the individual, 
they are either (a) symbolized, perceived, and organized into some relationship with the self, (b) ignored because there is no perceived relationship to the self-structure, (c) denied symbolization or given distorted symbolization because the experience is inconsistent with the structure of the self.

It can be adduced from the cognitive dissonance theory that once the self-concept is formed, whether positive or negative, the individual's perceptual processes will selectively screen environmental stimuli in an effort to maintain existing attitudes toward the self.

There is, however, a great deal of evidence that suggests self-concepts do change. Changes in the evaluative component of the self-concept have been shown in empirical studies relating to psychotherapy, age, ratings by a significant other, and experimentally manipulated success and failure.

Both Rogers (1961) and Raimy (1971) have noted that changes in a client's self-concept are a critical element in successful psychotherapy: Rogers (1961, p. 87) remarked, "We have established the fact that in successful psychotherapy negative attitudes toward the self decrease and positive attitudes increase. "Likewise, Raimy (1971, p. 125) noted that:

... in cases of successful counseling, the clients revealed estimation of self .... underwent a reversal from predominance of Negative SelfReference at the beginning of counseling to a very heavy weighting of Positive Self-Reference at the conclusion of counseling. 
Several investigators have found evidence of age related changes in self-esteem. However, the findings have been equivocal with regard to the direction of change. Howe (1973) found that the : self-esteem scores in three groups (ages 25-30, 45-55, and 60-70) gradually decreased from the youngest group to the oldest group, and attributed this decrease in self-esteem to the effects of the youth orientation of our society. Kogan and Wallach (1961) and Mason (1954) also found evidence of a decline in self-esteem with age. Conversely, Grant (1969) found that self-esteem increases with age, but speculated this may be due to an increase in denial with age rather than an increase in actual positive self-feelings. The results of studies by Bloom (1961), and Hess and Bradshaw (1970) indicated that the relationship between self-esteem and age is curvilinear increasing up to middle age, then decreasing. In view of the equivocal findings of previous studies on the relationship between selfesteem and aging, Kaplan and Pokorny (1970) suggested that the relationship is a conditional one, holding for populations with specific characteristics but not for those with other characteristics. The results of their study were supportive of this position.

Studies involving changes in self-esteem due to evaluations by significant others and experimentally manipulated success and failure, though they do indicate that self-esteem is susceptible to change, do not provide evidence of anything more than momentary 
change. Nevertheless, they are noted here because they do lend support to the notion that an individual's level of self-esteem does fluctuate.

Videbeck (1960), in a study involving the effect of evaluations by an "expert" on an individual's self-ratings regarding the attribute which was evaluated, found that subjects changed their self-ratings. in a positive direction if they received an approving evaluation and in a negative direction if they received a disapproving evaluation. A replication of Videbeck's study by Maehr, Mensing, and Nafzger (1962) produced similar findings. In a study by Gelfand (1962), changes in self-esteem were measured following experimentally manipulated success and failure experiences. The findings indicated subjects who experienced success rated themselves more favorably and subjects who experienced failure rated themselves less favorably.

In light of the foregoing it may be, as Blau (1973, p. 130) has suggested, that even though the foundations of the self-concept are formed in childhood, they are continuously being modified through interaction with others who become significant to people later in life.

\section{Effect of Institutionalization}

There has been considerable speculation that institutionalization itself is the critical factor affecting the self-esteem of 
institutional residents. Mason (1954) found that the institutionalized elderly had lower self-esteem than elderly respondents who were living independently. Lieberman, et al, (1968), after a comprehensive review of the literature, noted that cross-sectional studies comparing institutionalized elderly to elderly living in the community generally show that the institutional groups exhibit more negative psychological attributes, including low self-esteem, than the community samples.

However, the vast majority of previous studies examining the effects of institutionalization on self-esteem did not provide adequate controls for intervening variables. Anderson (1967) speculated that factors other than institutionalization itself were responsible for lower self-esteem among institutional residents. In order to control for the relationship between low self-esteem and choosing to live in an institution, subjects in this study were drawn from the residents of a retirement home and persons on the waiting list for admittance to the same home. Anderson found no significant difference in self-esteem between the institutional and noninstitutional samples. The data did reveal, however, that there was a significant relationship between the amount of social interaction and self-esteem in both groups. The relationship was in a positive direction with those subjects who maintained a high level of social interaction having higher self-esteem. It was concluded 
then, that change in the amount of social interaction, rather than institutionalization itself, is the necessary condition for lower selfesteem among institutional rèsidents. This conclusion was supported by Rosel (1972) who found that nursing home residents' involvement in the home was positively related to their self-concepts.

Relationship to Personal Satisfaction

The notion that self-esteem is related to personal satisfaction and effective functioning has received wide acceptance among theorists and investigators. Empirical evidence of this position is related to findings based on the characteristics of those individuals who have been found to possess either high or low self-esteem.

Coopersmith (1967, pp. 133-134) summarized his findings on the affective states of children with high and low. self-esteem as follows:

Persons with high self-esteem are expressive, happy, and relatively free of anxiety; persons with low self-esteem are less expressive, less happy, and relatively anxious.

Coopersmith's findings also indicated that there is a linear relationship between self-esteem and happiness. Rosenberg (1965, p. 158) provided the following description of individuals with low selfesteem:

People with low self-esteem, we find, (1) are much more likely to be sensitive to criticism...; (2) are much more bothered if others have a low 
opinion of them; (3) a re much more likely to be deeply disturbed if they do poorly at some task they have undertaken; (4) are much more likely to be disturbed when they become aware of some fault or inadequacy in themselves.

Mason (1954) found that a high level of self-worth was significantly related to a happy outlook on life in both institutionalized and community elderly. In a study with adult males, Luck (1969) concluded that persons with low self-esteem have a greater tendency to be "withdrawn", "submissive and dependent", "vulnerable in interpersonal relationships", and have problems in releasing hostility.

\section{SELF-ESTEEM IN THE AGED}

Research on the correlates of self-esteem in aged populations has been limited. However, the following studies do provide some indication of factors which may be related to the maintenance of self-esteem in the elderly. The findings of a study by Cameron. (1967) indicated that degree of independence was related to morale in an elderly population. Maddox (1963), in a longitudinal study using elderly subjects, found that increase in activity was related to an increase in morale and that a decrease in activity led to a decrease in morale. Klopfer (1958) found evidence that the more active elderly subjects in his study demonstrated higher self-esteem. Davis (1962) concluded from a study of 33 institutionalized subjects that the re was a positive relationship between self-estimates and effective social 
interaction. Lewis (1971) found that reminiscence in elderly subjects was related to increased past/present self-concept congruence and suggested that reminiscence may be a means of maintaining selfesteem in the elderly. Friedman (1967). found evidence that both chronological old age and long-term residence were highly valued attributes by home for the aged residents. He suggested that since these characteristics were held in high esteem by this population, residents who possessed them might be aided in maintaining a favorable conception of themselves.

Previously cited studies by Kaplan and Pokorny, Mason, and Anderson also noted finding correlates of self-esteem in elderly populations. Kaplan and Pokorny (1970, p. 248) found aging to be: associated with lower self-derogation when subjects:

(1) Reported no recent life experiences requiring behavioral adaptation; (2) reported no disparity between current and hoped-for standard of living; (3) reported as children they were not afraid of. being left alone; and (4) were living with spouses in independent households.

In Mason's (1954) sample of institutionalized elderly, subjects who were judged to have had a happy life, who maintained some intellectual interest, and who had a higher level of education exhibited higher selfesteem than subjects otherwise characterized. Anderson (1.967) found degree of social interaction and felt communality among institutional residents to be positively related to the self-esteem of the residents. 


\section{CONCLUSION}

There appears to be sufficient support in the literature for the theoretical propositions on which this study is based. The works of James (1952), Mead (1934), and Cooley (1964) indicate that an individual's level of self-esteem is a function of social interaction. The results of empirical studies by Rosenberg (1965), Coopersmith (1967), and Kahana and Coe (1969) support the proposition that an individual's immediate interpersonal environment provides the most important criteria for self-evaluation. The results of numerous studies (Rogers, 1961; Raimy, 1971; Videbeck, 1960; Maehr, et al, 1962; Gelfand, 1962) indicate that an individual's evaluation of himself is susceptible to change through interaction with others. The findings of Anderson's study (1967) on the influence of institutionalization on self-esteem indicate that institutionalization, per se, is not the critical factor affecting the self-esteem of institutional residents. Lastly, the findings of studies by Rosenberg (1965), Coopersmith (1967), and Luck (1969) indicate that persons with high self-esteem are generally happier, more comfortable and effective in social interaction than are persons with low self-esteem.

In view of the foregoing, it seems reasonable to conclude that the self-esteem of elderly institutional residents will be 
affected by factors in the institutional environment and that selfesteem is related to quality of life. 


\section{CHAPTER III}

\section{METHODOLOGY}

In view of the exploratory purpose of the study, a one-shot design was employed in which all the available residents of one home for the aged were tested. The reasons for surveying these residents were to ascertain if maintenance of self-esteem was a problem for them, and to identify factors which might be related to their selfesteem.

SELECTION AND CHARACTERISTICS OF SUBJECTS

\section{Selection}

Time limitations and the use of interviews to collect data made it necessary to select an institution, as the setting for the study, which had both a small population and a majority of residents physically and mentally capable of responding to an interview. The Pythian Home met both criteria. Permission to conduct the study in this facility was obtained from its administrator.

It was the original intent of the researcher to interview all 35 of the residents in the home. However, after discussing the physical and mental capabilities of each resident with the Director 
of Nursing Services, it was decided to exclude nine residents from the study. Of these nine residents, five were determined to be physically unable to participate (due to severe hearing loss or stroke effects) and four were classified as mentally unable to give appropriate responses (due to confusion or disorientation). The sample was further limited due to three residents refusing to participate in the study and one resident leaving for a month's vacation before being interviewed.

\section{Characteristics}

Of the 22 residents who participated in the study, 17 were women and five men, 17 were nursing-care and five boarding, and 13 lived in single rooms and nine in double. The mean age of the sample was 82.7 with a range of 63 to 97 years of age. The range for length of residence at the Pythian Home was four moinths to 18-1/2 years with a mean of 6.2 years. The range for education was seventh grade to college graduate with a mean of 9.5 years of schooling. In general, the subjects were in good health although most manifested some physical problems common to their age group (e.g., arthritis, deterioration of vision and hearing). Thirteen of the subjects were ambulatory. 


\section{INSTRUMENT AND PROCEDURE}

\section{Instrument}

Interviews were chosen as the method of collecting data because it was felt that elderly subjects would have difficulty filling out a questionnaire (due to physical limitations). The interview schedule contained 45 items, included both closed- and open-ended questions, and is presented in Appendix A. The schedule items included the 10 questions of Rosenberg's (1965) self-esteem scale (RSE) as well as items designed to identify variations in the subjects' demographic characteristics, activities, feelings, and opinions which could be codified and tested for relationship to self-esteem. Rosenberg's self-esteem scale was designed primarily for an adolescent population, but has previously been used with adult populations. It was chosen as the self-esteem measure for this study because of its brevity and ease of administration. The other schedule items were designed to elicit responses in the following areas thought to be related to self-esteem: demographic information (e.g., age, sex, education, length of residence in the home, etc.), visits by significant others, activities, felt communality with other residents, feelings about staff, reminiscence, assessment of how well one has lived up to what he expected of himself, and personal assessment of the most important things in life. Data regarding two 
other variables, the subjects' residence status (boarding or nursing) and room occupancy (single or double), were obtained from the Director of Nursing Services.

The instrument was pretested, twice, by interviewing residents of two other nursing homes. Subjects were selected for the pretests on the basis of their similarity to Pythian Home residents. The purpose of the pretests was to determine if the questions were understandable to elderly respondents. The instrument was refined by dropping some questions and rewording others after each of the pretests.

Procedure

A copy of the Pythian Home's list of residents was obtained from the administrator's office. The Director of Nursing Services was asked to write the room number of each resident who had been deemed capable of responding to an interview, on the list of residents.

'On approaching each of the se residents, the interviewer introduced himself as a graduate student from Portland State University and stated that he was interviewing residents of the home to collect information to be used in a Master's thesis. The purpose of the interviews, as presented to the residents, was to obtain information about how they think and feel about different things. The subjects were told that participation in the study was voluntary and that their 
individual responses would be kept confidential. Each resident, was then asked if she, or he, would consent to being interviewed. If the resident agreed to the interview, the schedule items were read and the resident's responses recorded on $5 \times 8$ cards.

All interviews were conducted in private, either in the subject's room or in another private setting within the facility. The length of the interviews ranged from about 45 to 90 minutes depending on the physical capabilities and verbal responsiveness of the subject. Although some interviews took two sessions to complete due to time conflicts, the vast majority was completed in one session.

\section{DEFINITION OF VARIABLES}

Self-esteem was defined as a personal judgment of one's feeling of worth as reflected in the positive and/or negative attitudes one expresses toward oneself. Positive and negative attitudes toward the self were measured by constructing a nine-point Guttman scale using the ten items of Rosenberg's self-esteem scale. Of the ten self-esteem questions, there is an equal number for which "agree" and "disagree" responses indicate high self-esteem. These were presented alternately during the interview in an attempt to reduce the effect of respondent set. The range of scores on the scale was zero to eight with a low score indicating high self-esteem and a high 
score indicating low self-esteem. The scale items and method of scoring are presented in Appendix B. The scale had a coefficient of reproductibility of $93 \%$.

According to Rosenberg (1965, p. 31):

High self-esteem, as reflected on our scale items, expresses the feeling that one is "good enough." The individual simply feels that he is a person of worth; he respects himself for what he is, but he does not stand in awe of himself nor does he expect others to stand in awe of him ... Low self-esteem, on the other hand, implies self-rejection, self-dissatisfaction, selfcontempt. The individual lacks respect for the self he observes. The self-picture is disagreeable, and he wishes it were otherwise.

The nature of the group's responses to questions related to feelings about staff, how well they had lived up to expectations of themselves, and assessment of the most important things in life, precluded their being codified and tested for relationship to selfesteem. Variables tested for possible relationship to self-esteem were sex, age, education, residence status, room occupancy, selfrated health, length of residence, communality, visits by a significant other, reminiscence, and participation in crafts. In order to test for relationships between these variables and self-esteem, the sample was divided into groups which possessed different characteristics relative to each variable. Definitions of the variables and the method of dividing the sample into groups within each variable are listed below. 
1. Sex was defined as the person's gender. The sample was. divided into male and female groups for statistical comparison.

2. Age was defined as the subjects' chronological age at their last birthday; Subjects were divided into groups comprised of those whose age was above the mean age of the sample and those whose age was below the sample's mean age.

3. Education was defined as the number of years of formal schooling. Residents were divided into groups comprising those whose level of education was above the mean number of years of schooling of the sample and those whose educational level was below the sample mean.

4. Residence status was defined as the subject's classification, by the home, as either a boarding or nursing care resident. The se two groups were compared.

5. Room occupancy was defined as the number of individuals living in the subject's room. Subjects were divided into groups comprised of those who lived in a single occupancy room and those who lived in a double occupancy room.

6. Health was defined as the individual's rating of the status of his health compared to other people his age. The rating categories included excellent, good, fair, poor, and very poor. The subjects were divided into groups with those who 
indicated excellent or good health comprising one group and those who indicated fair, poor, or very poor health comprising the other group.

7. Length of residence was defined as the number of years (to the nearest half year) of residence in the Pythian Home. Subjects were divided into groups comprised of those whose length of residence was greater than the mean length of residence for the sample and those whose length of residence was less than the sample mean.

8. Communality was defined as the individual's perception that he had things in common with the other residents in the home. Subjects were divided into groups comprised of those who felt they had things in common with other residents and those who felt they had little or nothing in common with other residents.

9. Visits by a significant other were defined as visits, within the home, by friends or relatives. Subjects were divided into groups consisting of those who were visited by a significant other at least once a month and those who were visited by a significant other less than once a month.

10. Reminiscence was defined as thinking about one's past experiences. Comparison groups were subjects who indicated frequently thinking about their past and subjects who indicated they infrequently thought about their past. 
11. Participation in crafts was defined as taking part in the crafts program provided by the home. Residents were divided into groups comprised of those who indicated frequent participation and those who indicated infrequent or no participation in crafts.

\section{METHODS OF ANALYSIS}

In order to facilitate inferential analysis of the 11 variables, null hypotheses were formulated regarding the difference between the mean self-esteem scores of the groups within each of the variables. Each null hypothesis stated that the difference between the mean selfesteem scores of the groups would not be statistically significant. The .05 level of confidence was set as the criterion for rejection of each null hypothesis. The tests for statistical significance were Student's t's (two-tailed).

The sample's self-esteem scores were analyzed, using descriptive statistics (mean, mode, and standard deviation), in order to determine its level of self-esteem. In order to investigate characteristics of the subjects' self-esteem, responses to the self-esteem scale items were analyzed by computing the number of positive responses to each scale item. Responses to questions dealing with feelings about staff, how well the subjects had lived up to what they expected of themselves, and assessment of the most important things 
in life could not be codified for inferential analysis due to their ambiquity and/or overwhelming similarity. These responses were, however, analyzed verbally.

\section{LIMITATIONS OF THE STUDY}

The study will be limited by several factors including its exploratory nature, the use of a small sample which was not randomly selected, and the use of a self-esteem measure designed primarily for an adolescent population. Since this is an exploratory study, the re will be no in depth analysis of cause-effect relationships between self-esteem and hypothetically related variables. The primary intent of the study is to examine the efficacy of this line of inquiry and, hopefully, to provide information to aid the focus of future research in this area. The use of a purposive sample restricts the generalizability of the findings. Therefore, the results of the study will be limited to the population studied, and may be viewed as providing only suggestive evidence regarding the relationship between selfesteem and the tested variables. The use of a self-esteem measure designed primarily for adolescents limits the reliability of the findings. Although this instrument (RSE) has been previously used with adult populations, further investigation is needed to determine its validity and reliability as a measure of self-esteem in adults. 


\section{CHAPTER IV}

$$
\text { RESULTS }
$$

Analysis and discussion of the results of the study will be presented in three sections. The first section will describe the distribution of the sample's self-esteem scores and responses to the self-esteem scale items. The second section will include the presentation and analysis of the self-esteem scores of the comparison groups. The last section will examine the subjects' responses to opentended questions which could not be codified for statistical analysis.

\section{SELF-ESTEEM ANALYSIS}

A frequency distribution of the subjects' scores on the selfesteem scale is presented in Table I. The sample had a mean selfesteem score of 2.86 with a standard deviation of 2.24 . The modal score was zero.which reflects the highest level of self-esteem measured by the scale. Only $18 \%$ of the residents had scores in the five through eight range, which indicates low self-esteem. Thus, the residents' scores were heavily skewed toward the high selfesteem end of the scale. Although changes in the subjects' level of 
self-esteem were not measured, these findings suggest that, in general, maintenance of self-esteem was not a critical problem for the residents of this facility.

\section{TABLE I}

FREQUENCY DISTRIBUTION OF SELF-ESTEEM SCORES

\begin{tabular}{cccc}
\hline & Scores & Frequency & Percent of Total \\
\hline High & 0 & 5 & 22.7 \\
& 1 & 1 & 4.5 \\
& 2 & 4 & 18.1 \\
& 3 & 4 & 18.1 \\
4 & 4 & 1 & 18.1 \\
& 5 & 1 & 4.5 \\
& 6 & 1 & 4.5 \\
& 7 & 1 & 4.5 \\
\hline Low & & 22 & 4.5 \\
\hline
\end{tabular}

* Less than $100 \%$ due to errors of rounding.

The subjects' responses to the self-esteem scale items were analyzed in an effort to determine the structure of their self-esteem (see Table II). Twenty-one residents agreed with the item "I feel that I am a person of worth, at least on an equal plane with others." Twenty residents agreed with the item, "On the whole, I am satisfied with myself." The nature of these items, and the fact that a large majority of the subjects agreed with them, indicates that the Pythian 
TABLE II

POSITIVE RESPONSES TO SELF-ESTEEM SCALE ITEMS

\begin{tabular}{lll}
\hline \multicolumn{1}{c}{ Item } & Positive Response & N \\
\hline $\begin{array}{l}\text { I certainly feel useless at times. } \\
\text { At times I think I am no good at all. }\end{array}$ & Agree & 15 \\
$\begin{array}{l}\text { I wish I could have more respect } \\
\text { for myself. }\end{array}$ & Agree \\
$\begin{array}{l}\text { I feel I do not have much to be } \\
\text { proud of. }\end{array}$ & Agree \\
$\begin{array}{l}\text { I am able to do things as well as } \\
\text { most other people. }\end{array}$ & Agree \\
$\begin{array}{l}\text { I take a positive attitude toward } \\
\text { myself. }\end{array}$ & Disagree \\
$\begin{array}{l}\text { I have a number of good qualities. } \\
\begin{array}{l}\text { On the whole, I am satisfied with } \\
\text { myself. }\end{array}\end{array}$ & Disagree \\
$\begin{array}{l}\text { All in all, I am inclined to feel that } \\
\text { I am a failure. }\end{array}$ & Disagree \\
$\begin{array}{l}\text { I feel that I am a person of worth, at } \\
\text { least on an equal plane with others. }\end{array}$ & & \\
\hline \hline
\end{tabular}

Note: Positive responses indicate low self-esteem.

Home residents had a strong sense of intrinsic worth. However, fifteen of the residents also agreed with the item, "I certainly feel useless at times." This finding indicates that in spite of the residents' strong feeling of intrinsic worth, they still viewed themselves as being useless. Thus, it would appear that even though the institutional 
environment may not have affected the residents'. global self-e steem, it may have affected their sense of usefulness.

\section{COMPARISON GROUPS ANALYSIS}

Statistical Analysis

The results of the $t$-tests for significant differences between the mean self-esteem scores of the eleven comparison groups are presented in Table III. The results of those tests indicate that only two of the eleven tested variables, self-rated health and length of residence, were significantly related to self-esteem in the Pythian Home residents.

The comparison groups for self-rated health were subjects who rated their health as either excellent or good and those who rated their health as fair or poor. The excellent-good group had a mean self-esteem score of 2.1 with a standard deviation of 1.78. The fair-poor group's mean self-esteem score was 5.4 with a standard deviation of 1.74 . The $t$ value for the difference between the means was 4.17 which is significant at the .05 level of confidence. Therefore, the null hypothesis of no significant difference between the mean self-esteem scores of the two groups was rejected. As a result of this finding, it may be inferred that there was a significant relationship between self-esteem and health in this sample: The direction of the difference indicates that those subjects who rated 
TABLE III

SELF-ESTEEM MEANS, STANDARD DEVIATIONS, AND $T$ VALUES OF COMPARISON GROUPS

\begin{tabular}{|c|c|c|c|c|c|}
\hline Variable & Groups & $\mathrm{N}$ & Mean & S. D. & $t$ \\
\hline Sex & $\begin{array}{l}\text { Male } \\
\text { Female }\end{array}$ & $\begin{array}{r}5 \\
17\end{array}$ & $\begin{array}{l}3.4 \\
2.7\end{array}$ & $\begin{array}{l}2.65 \\
2.07\end{array}$ & .66 \\
\hline Age & $\begin{array}{l}\text { Above* } \\
\text { Below* }\end{array}$ & $\begin{array}{r}15 \\
7\end{array}$ & $\begin{array}{l}2.66 \\
3.28\end{array}$ & $\begin{array}{l}1.81 \\
2.91\end{array}$ & .58 \\
\hline Education & $\begin{array}{l}\text { Above* } \\
\text { Below* }\end{array}$ & $\begin{array}{r}8 \\
14\end{array}$ & $\begin{array}{l}2.5 \\
3.07\end{array}$ & $\begin{array}{l}2.38 \\
2.12\end{array}$ & .57 \\
\hline Residence Status & $\begin{array}{l}\text { Boarding } \\
\text { Nursing }\end{array}$ & $\begin{array}{r}5 \\
17\end{array}$ & $\begin{array}{l}1.8 \\
3.05\end{array}$ & $\begin{array}{l}1.17 \\
2.38\end{array}$ & 1.58 \\
\hline Room Occupancy & $\begin{array}{l}\text { Single } \\
\text { Double }\end{array}$ & $\begin{array}{r}13 \\
9\end{array}$ & $\begin{array}{l}2.85 \\
2.88\end{array}$ & $\begin{array}{l}2.41 \\
1.97\end{array}$ & .03 \\
\hline Health. & $\begin{array}{l}\text { Excellent-Good } \\
\text { Fair-Poor }\end{array}$ & $\begin{array}{r}17 \\
5\end{array}$ & $\begin{array}{l}2.1 \\
5.4\end{array}$ & $\begin{array}{l}1.78 \\
1.74\end{array}$ & $4.17 * *$ \\
\hline Length of Residence & $\begin{array}{l}\text { Above* } \\
\text { Below* }\end{array}$ & $\begin{array}{r}8 \\
14\end{array}$ & $\begin{array}{l}4.5 \\
1.86\end{array}$ & $\begin{array}{l}2.45 \\
1.40\end{array}$ & $3.07 *$ \\
\hline Communality & $\begin{array}{l}\text { Yes } \\
\text { No }\end{array}$ & $\begin{array}{l}11 \\
11\end{array}$ & $\begin{array}{l}2.54 \\
3.18\end{array}$ & $\begin{array}{l}1.62 \\
2.69\end{array}$ & .66 \\
\hline Visitation & $\begin{array}{l}\text { Frequent } \\
\text { Infrequent }\end{array}$ & $\begin{array}{l}11 \\
11\end{array}$ & $\begin{array}{l}3.09 \\
2.63\end{array}$ & $\begin{array}{l}2.27 \\
2.18\end{array}$ & 46 \\
\hline Reminiscence & $\begin{array}{l}\text { Frequent } \\
\text { Infrequent }\end{array}$ & $\begin{array}{l}10 \\
12\end{array}$ & $\begin{array}{l}3.5 \\
2.33\end{array}$ & $\begin{array}{l}2.46 \\
1.88\end{array}$ & 1.21 \\
\hline Crafts & $\begin{array}{l}\text { Frequent } \\
\text { Infrequent }\end{array}$ & $\begin{array}{l}10 \\
12\end{array}$ & $\begin{array}{l}2.30 \\
3.33\end{array}$ & $\begin{array}{l}1.62 \\
2.56\end{array}$ & 1.09 \\
\hline
\end{tabular}


their health in a positive manner had higher self-esteem than those who rated their health in negative terms.

The comparison groups for length of residence were subjects whose term of residence in the Pythian Home was above the sample mean ( 6.2 years) and those whose term of residence was below the sample mean. The above group had a mean self-esteem score of 4. 5 with a standard deviation of 2.45. The below group had a mean score of 1.86 with a standard deviation of 1.40 . The difference between the mean self-esteem scores of the two groups was significant $(t=3.05)$ at the .05 level of confidence. The null hypothesis of no significant difference between the groups' self-esteem scores was, therefore, rejected. The results suggest that subjects who had lived in the Pythian Home for a shorter period of time had higher selfesteem.

This finding contradicts Friedman's (1967) contention that long-term residence may be a valued characteristic by home for the aged residents and thus aid residents with that characteristic in maintaining a favorable self-conception. However, the results of this study indicate that further research, with more refined methodologies, will be needed in order to clarify the relationship between length of residence and self-esteem. T-test analyses of the self-esteem means of the comparison groups within the remaining nine variables indicated that those 
variables were not significantly related to self-esteem in Pythian Home residents. In order to avoid redundancy, statistical findings relative to those variables will not be presented here (see Table III). However, the direction of the difference in self-esteem between the comparison groups comprising each variable is presented in the following list.

1. Females had higher self-esteem than males.

2. Boarding residents had higher self-esteem than nursing residents.

3. There was virtually no difference between the self-esteem means of residents who lived in single rooms and those who lived in double rooms.

4. Residents who noted having things in common with their peers had higher self-esteem than those who noted having little or nothing in common with other residents.

5. Frequent participants in crafts had higher self-esteem than infrequent participants.

6. Residents who had frequent visits by a significant other had slightly lower' self-esteem than those who had infrequent visits.

7. Frequent reminiscers had lower self-esteem than infrequent reminiscers.

8. Residents who had more education had higher self-esteem than those with less education. 
9. Older residents had higher self-esteem than younger residents.

Relationship to Previous Findings

The direction of the difference in the self-esteem scores of the comparison groups for reminiscence was contrary to previous research findings. Specifically, Lewis (1971) found evidence that reminiscence was related to high self-esteem in elderly subjects. However, the negative relationship found between self-esteem and reminiscence in this study may have been due to the fact that reminiscence was defined as thinking rather than talking about one's past. Perhaps the social reinforcement one receives while talking with others about one's past affects the nature of the relationship between self-esteem and reminiscence.

The direction of the difference in self-esteem between the groups differentiated by felt communality, education, and age was supportive of previous research findings. Anderson (1967) also found a positive relationship between self-esteem and communality. In a study by Mason (1954), elderly subjects who had a higher level of education also had higher self-esteem. In a study of the institution-. alized aged, Friedman (1967) found that older residents were more popular and suggested that this might assist them in maintaining selfesteem. 
In order to further clarify the relationship between age and self-esteem, the data on those variables were further analyzed by comparing the mean self-esteem scores of three age groups (below 80, 80-90, and above 90). There was negligible difference between the mean scores of the below 80 and $80-90$ groups. However, those residents who were above 90 years of age had noticeably higher selfesteem than both of the younger groups (see Table IV). This finding indicates that, although there was not a linear relationship between self-esteem and age, there was a positive relationship between extreme chronological old age and self-esteem.

TABLE IV

MEAN SELF-ESTEEM SCORES OF AGE GRÖUPS

\begin{tabular}{lll}
\hline Age Groups & $\mathrm{N}$ & Mean \\
\hline Below 80 & 7 & 3.28 \\
80 to 90 & 11 & 3.18 \\
Above 90 & 4 & 1.25 \\
\hline
\end{tabular}

\section{DESCRIPTIONS OF UNCODIFIED RESPONSES}

'The subjects' responses to questions dealing with their feelings about the staff, how well they had lived up to personal expectations, and their assessments of the most important things in 
life, could not be codified for statistical analysis. However, the trend of the subjects' responses to each of those questions will be described.

The residents' responses to the question regarding their feelings about the staff were all positive. Typical responses were: "They are awfully nice," and, "I think we have a remarkably good staff all along the line." The residents depicted the staff as being both pleasant and helpful as typified by the following comments: "They are always trying to find something for us to do to make us feel better," "They make everybody feel at home," and, "They are agreeable and nice about things we do."

The residents' responses appeared to be genuine expressions of positive regard for the staff. The interviewer was impressed by the positive quality of observed interactions between the staff and residents. In addition, the residents did not appear to feel threatened in evaluating the staff. This was exemplified by statements such as, "Most of them are very good - they have to be," and, "They have treated me all right so far - they'd better."

In view of the likelihood that staff members are significant others in the lives of the residents, the fact that resident-staff interactions are overwhelmingly positive may be a primary reason for the sample's relatively high level of self-esteem.

The diverse and often ambiguous nature of the subjects' 
evaluations of how well they had lived up to personal expectations made this variable impossible to analyze statistically. Only five residents were able to state unequivocally that they had $(n=2)$ or had not $(n=3)$ lived up to personal expectations. Most of the residents gave responses which could be described as qualified positive assessments (e.g., "There are things I would change, but... (I've done) O.K.") In addition, several subjects stated they had never given the question any thought.

There was also little uniformity in the residents "delineations of the most important things in life. Being good to others, good health, and religion were each mentioned six times. Friendship, love, and morals were each named by three residents. Notably, money, activity, and independence, all highly valued in our society, were each named only once. In spite of the lack of consensus in the subjects' specific responses, it appears that the majority of Pythian Home residents considers some form of positive interpersonal interaction (i.e., being good to others, friendship, or love) as the most important thing in life. 


\section{CHAPTER V}

\section{SUMMARY AND CONCLUSIONS}

In order to explore both the nature of and factors related to self-esteem in the institutionalized aged, a 45 -item interview schedule was administered to 22 residents of a home for the aged. The interview schedule included Rosenberg's self-esteem scale and items designed to identify variations in the subjects' demographic characteristics, activities, feelings, and opinions which could be codified and tested for relationship to self-esteem.

The following eleven variables were tested for their relationship to self-esteem: sex, age, education, residence status (nursing or boa rding), room occupancy (single or double), health, length of residence, communality with other residents, visits by a significant other, reminiscence, and participation in crafts. In order to test. the relationship of each variable to self-esteem, subjects who manifested different characteristics with regard to each of the variables were divided into comparison groups. T-tests for differences between the mean self-esteem scores of the comparison groups were used to test for significant relationships between self-esteem and each of the variables. 
Examination of the subjects' self-esteem scores revealed that, in general, they did not have low global self-esteem. The residents' responses to the individual self-esteem scale items indicated that they had a high sense of intrinsic worth, but also tended to feel useless.

The results of the $t$-test analyses revealed that only two of the eleven tested variables were related to self-esteem at the .05 level of significance. These were health and length of residence. Residents who rated their health in positive terms had higher selfesteem than those who rated their health in more negative terms and short-term residents had higher self-esteem than long-term residents:"

Although the differences were not statistically significant, comparison of the mean self-esteem scores of the groups comprising the remaining nine variables indicated that, (1) females had higher self-esteem than males; (2) boarding residents had higher selfesteem than nursing residents; (3) there was virtually no difference in self-esteem between single room and double room occupants; (4) subjects who noted having things in common with other residents had higher self-esteem than those who did not; (5) frequent participants in crafts had higher self-esteem than infrequent participants; (6) residents who had frequen't visits by a significant other had slightly lower self-esteem than those who had infrequent visits; (7) frequent remin-- 
iscers had lower self-esteem than infrequent reminiscers; (8). residents who had more education had higher self-esteem than those with less education; and, (9) older residents had higher self-esteem than younger residents.

This study does not, and was not intended to, provide findings which could be generalized to the institutionalized elderly as a whole. Rather, the purpose of the research was to explore self-esteem in a sample of institutionalized elderly persons in order to identify areas of content, within that topic, which might be productively investigated in more controlled studies. In this vein, the results of this study suggest: (1) Further studies are needed to identify the extent of low self-esteem in the institutionalized elderly (it was not widespread in this sample); (2) both health and length of residence may be significantly related to self-esteem in the institutionalized elderly; and; (3) feelings of uselessness may be a more pervading problem for the institutionalized elderly than maintenance of global self-esteem. 


\section{REFERENCES}

Anderson, Nancy N. "Effects of Institutionalization on Self-Esteem,". Journal of Gerontology 22 (July 1967): 313-317.

Back, Kurt W. "Transition to Aging and the Self-Image," Aging_and Human Development 2 (November 1971): 296-304.

Blau, Zena Smith. Old Age in a Changing_Society, New York: New Viewpoints - A Division of Franklin Watts, Inc., 1973.

Bloom, Kenneth L. "Age and the Self Concept," The American Journal of Psychiatry 118 (December 1961): 534-538.

Branden, Nathaniel. The Psychology of Self-Esteem, Los Angeles: Nash Publishing Corporation, 1969, Bantam Books, 1976.

Brody, Elaine M. "Aging," In Encyclopedia of Social Work, 16th ed., pp. 51-71, Edited by Robert Morris; New York: National Association of Social Workers, Inc, 1971.

Cameron, Paul. "Ego Strength and Happiness of the Aged," Journal of Gerontology 22 (April 1967): 199-202.

Cohen, Arthur R. "Some Implications of Self-Esteem for Social Influence," In Personality and Persuasibility, pp. 102-120, Edited by Carl I. Hovland and Irving L. Janis, New Haven: Yale University Press; 1959.

Cooley, Charles Horton. Human Nature and Social Order, Revised ed. New York: Schocken Books, 1964.

Coopersmith, Stanley. The Antecedents of Self-Esteem, San Francisco: W. H. Freeman and Company, 1967.

Davis, Robert W. "The Relationship of Social Preferability to Self-' Concept in an Aged Population, " Journal of Gerontology 17 (October 1962): $431-436$. 
Entman, Sidney. "Another Approach to Nursing Home Care," Geriatrics 16 (December 1961): 651-654.

Festinger, Leon. A Theory of Cognitive Dissonance, Stanford: Stanford University Press, 1957.

Freidman, Edward P. "Age, Length of Institutionalization, and Social Status in a Home for the Aged," Journal of Gerontology 22 (October 1967): 474-477.

Gelfand, Donna M. "The Influence of Self-Esteem on Rate of Verbal Conditioning and Social Matching Behavior," Journal of Abnormal and Social Psychology 65 (October 1962): 259-265.

Gordon, Susan K. and Vinacke, W. Edgar. "Self- and Ideal SelfConcepts and Dependency in Aged Persons Residing in Institutions," Journal of Gerontology 26 (July 1971): 337-343.

Grant, Carmen Hill. "Age Differences in Self-Concept from Early Adulthood through Old Age," Proceedings of the American Psychological Association 77 (1969): 717-718.

Hess, Anne L. and Bradshaw, H. L. "Positiveness of Self-Concept and Ideal Self as a Function of Age," The Journal of Genetic Psychology 1.17 (1970): 57-67.

Howe, Margot C. "A Comparison of the Self-Esteem, Body Image and Movement-Concept of Adults in Different Age Groups," Dissertation Abstracts International 34 (November, 19.73): $2258 \mathrm{~A}-2259 \mathrm{~A}$.

James, William. The Principles of Psychology, Great Books of the Western. World, Vol. 53, Edited by Robert Maynard Hutchins, Chicago: Encyclopaedia Brittanica, Inc., 1952.

Kahana, Eva and Coe, Rodney M. "Self and Staff Conceptions of Institutionalized Aged," The Gerontologist 9 Part I (Winter 1969): 264-267.

Kaplan, Howard B. and Pokorny, Alex D. "Aging and Self-Attitude: A Conditional Relationship," Aging and Human Development 1 (July 1970): 241-250.

Klopfer, Walter G. "Psychologic Stresses of Old Age," Geriatrics 13 (August 1958): 529-531. 
Kogan, Nathan and Wallach, Michael A. "Age Changes in Values and Attitudes," Journal of Gerontology 16 (July 1961): 272-280.

Kosberg, Jordan J. "The Nursing Home: A Social Work Paradox," Social Work 18 (March 1973): 104-110.

Lepkowski, J. Richard. "The Attitudes and Adjustments of Institutionalized and Non-Institutionalized Catholic Aged," Journal of Gerontology 11 (April 1956): 185-191.

Lewis, Charles N. "Reminiscing and Self-Concept in Old Age," Journal of Gerontology 26 (April 1971): 240-243.

Lieberman, Morton A.; Prock, Valencia N. ; and Tobin, Sheldon S. "Psychological Effects of Institutionalization," Journal of Gerontology 23 (July 1968): 343-353.

Luck, Patrick William. "Social Determinants of Self-Esteem," Dissertation Abstracts 30 (August 1969): $810 \mathrm{~A}$.

Luck, Patrick W., and Heiss, Jerold. "Social Determinants of SelfEsteem in Adult Males," Sociology_and Social Research 57 (October 1972): 69-84.

Maddox, George L. "Activity and Morale: A Longitudinal Study of Selected Elderly Subjects," Social Forces 42 (December 1963): 195-204.

Maehr, Martin L.; Mensing, Josef; and Nafzer, Samuel. "Concept of Self and the Reaction of Others," Sociometry 25 (December 1962): $353-357$.

Mason, Evelyn P. "Some Correlates of Self-Judgments of the Agëd;" Journal of Gerontology 9 (July 1954): 324-337.

McDavid, John W. and Harari, Herbert. Psychology and Social Behavior, New York: Harper \& Row, 1974.

Mead, George H. Mind, Self and Society, Chicago: The University of Chicago Press, 1934.

Morse, Stan and Gergen, Kenneth J. "Social Comparison, SelfConsistency, and the Concept of Self," Journal of Personality and Social Psychology 16 (September 1970): 148-156. 
Raimy, Victor Charles. The Self-Concept as a Factor in Counseling and Personality Organization, by the Office of Educational Services, The Ohio State University Libraries, 1971.

Rogers, Carl R. Client-Centered Therapy, Boston: Houghton Mifflin Company, 1951.

Rogers, Carl R. On Becoming a Person, Boston: Houghton Mifflin Company, Sentry ed., 1961.

Rosel, Natalie Elaine. "Self-Concepts of Institutionalized Older People," Dissertation Abstracts International 32 (MarchApril 1972): $5339 \mathrm{~A}$.

Rosenberg, Morris. Society and the Adolescent Self-Image, Princeton: Princeton University Press, 1965.

Routh, Thomas A. Nursing Homes, Springfield: Charles C. Thomas, 1968.

Schwartz, Arthur N. "An Observation on Self-Esteem as the Linchpin of Quality of Life for the Aged, An Essay, "The Gerontologist 15 (October 1975): 470-472.

Siporin, Max. Introduction to Social Work Practice, New York: MacMillan Publishing Company, Inc., 1975.

Videbeck, Richard. "Self-Conception and the Reactions of Others," Sociometry 23 (December 1960): 351-359.

Webster, Jr., Murray and Sobieszek, Barbara. Sources of SelfEvaluation, New York: John Wiley \& Sons, Inc., 1974.

Wylie, Ruth C. The Self-Concept, Revised ed. Lincoln: University of Nebraska Press, 1974. 


\section{APPENDIX A}

\section{INTERVIEW SCHEDULE}

The information gathered by this interview will be used in my Master's Thesis. The purpose of the interview is to find out what people think and feel about different things. The re are no right or wrong answers to the questions. Your individual responses will be kept confidential and your participation in the study is volunatry. Your cooperation in this study will be very helpful and greatly appreciated.

First, I would like to get some general information about you.

1. Age at last birthday:

2. With regard to age, do you think of yourself as: elderly very old Other (specify): middle-aged $\begin{array}{ll}\text { Sex: Male } & \text { Female } \\ \begin{array}{c}\text { Marital status: } \\ \text { widower }\end{array} \text { mever been married. }\end{array}$

5. How many children do you have? Living

6. How often do you have contact with them (probe for number of letters, phone calls, and visits)? Quality of Contacts?

7. How many grandchildren do you have?

8. How often do you have contact with them (probe for number of letters, phone calls, and visits)? Quality of contacts?

9. Are there other people outside Pythian Home who are important to you? What is your relationship with them (friend, relative, etc.)? 
10. How often do you have contact with them (probe for number of letters, phone calls, visits)? Quality of contacts?

11. Education (highest level completed):

12. What is the job you worked at most of your. life?

13. How well did you like your job? ___ very well __ a little not much not at all.

14. What is the job your husband/wife worked at most of his/her. life?

15. About how long have you been retired or how long since you were a housewife?

16. Before you (your husband) retired from work do you remember how much money you (he) used to earn?

17. How well did you get along with that income (probe for specifics)?

18. : How would you rate your health compared to other people your age? excellent. good fair very poor

19. Have there been changes in your health in the last year?

20. What is your religious preference?

21. How often do you attend church services (probe for specifics, weekly, once a month, etc.)?

Next, I will read some statements about how you might feel about yourself. After reading each statement I will ask whether you strongly agree, agree, disagree, or strongly disagree with the statement.

22. I feel that I am a person of worth, at least on an equal plan with others. SA A SD

23. I feel I do not have much to be proud of. SA A D SD 
24. I feel I have a number of good qualities. SA D SD

25. All in all, I am inclined to feel that I am a failure. SA A D $\mathrm{SD}$

26. I am able to do things as well as most other people. SA $\longrightarrow \mathrm{A} \longrightarrow \mathrm{SD}$

27. I wish I could have more respect for myself. SA A D SD

28. I take a positive attitude toward myself. SA D $S D$

29. I certainly feel useless at times. SA A $\quad D$ SD

30. On the whole, I am satisfied with myself. SA A D SD

31. At times, I think I am no good at all. SA A $\mathrm{D}$ $\mathrm{SD}$

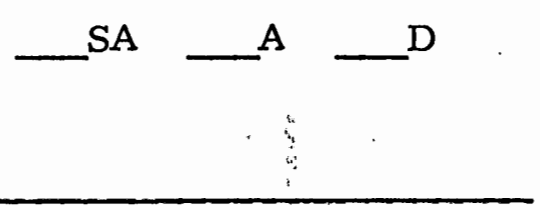

Next, I would like to get some information about you in Pythian Home.

32. How long have you been residing here?

33. Who pays Pythian Home for taking care of you (self, relatives, etc.)?

34. How do you spend your days (get detailed time schedule, how often they participate in activities provided by the home, etc.)?

35. Are there certain things the staff expects you to do (rules of the home, participate in certain activities, etc.)?

36. How do you feel about these things?

37. What are some things you share in common with other residents here?

38. How do you feel about the staff (positive, negative)? 
39. What are some of the things they do for you that make you feel important or special?

40. Do you think they treat everybody like they treat you?

The last group of questions relate to your past life.

41. How often do you think about your past experiences?

42. How often do you talk about your past experiences?

43. Do you find thinking and talking about past experiences enjoyable?

44. In general, how well would you say you have lived up to what you expected of yourself?

45. What do you think are the most important things in life ? 


\section{APPENDIX B \\ SELF-ESTEEM SCALE AND SCORING}

The scale items are presented in order from the strongest to the weakest responses. "Postive" responses are indicated by asterisks and indicate low self-esteem. Where contrived items have been used the basis for their scoring is indicated.

\section{Scale Item I}

I certainly feel useless at times.

*1_____ Strongly agree

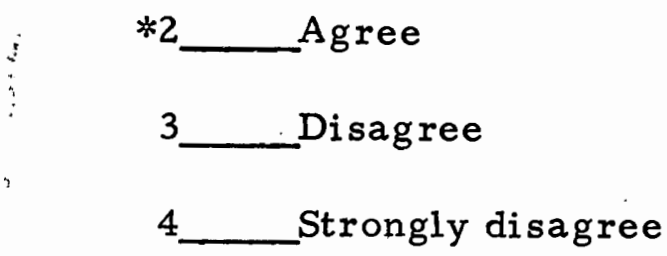

Scale Item II was contrived from the combined responses to two selfesteem questions. One out of two or two out of two positive responses were considered positive for Scale Item II.

At times I think I am no good at all.

$* 1$ Strongly agree

*2 Agree

3 Disagree

4 Strongly disagree 
I wish I could have more respect for myself.

$* 1 \_$Strongly agree
$* 2 \_$Agree
$3 \_$Disagree
$4 \_$Strongly disagree

Scale Item III

I feel I do not have much to be proud of.

$* 1 \ldots$ Strongly agree
${ }_{2}^{*}$ Agree
$3 \_$Disagree
$4 \_$Strongly disagree

Scale Item IV

I am able to do things as well as most other people.

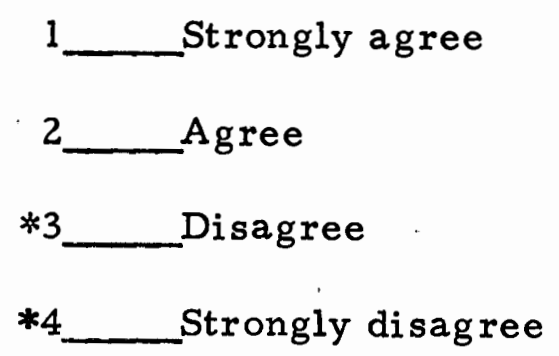

Scale Item V

I take a positive attitude toward myself.

1 ___ Strongly agree

2 A Agree

*3___ Disagree

*4____ Strongly disagree 


\section{Scale Item VI}

I feel that I have a number of good qualities.

$$
\begin{aligned}
& 1 \text { ___ Strongly agree } \\
& 2 \text { Agree } \\
& \text { *3___ Disagree } \\
& \text { *4____ Strongly disagree }
\end{aligned}
$$

Scale Item VII was contrived from the combined responses to two self-esteem questions. One out of two or two out of two positive responses were considered positive for Scale Item VII.

On the whole, I am satisfied with myself.

$$
\begin{aligned}
& 1 \_ \text {Strongly agree } \\
& 2_{* 3}^{1} \text { Agree } \quad \text { Disagree } \\
& * 4 \_ \text {Strongly disagree }
\end{aligned}
$$

All in all, I am inclined to feel that I am a failure.

*1____ Strongly agree

*2___ Agree

3 ___ Disagree

4 Strongly disagree 
Scale Item VIII

I feel that I'm a person of worth, at least on an equal plane with others.

I___ Strongly agree

2 Agree

*3___ Disagree

*4___ Strongly disagree 